\title{
Canadian collaboration aims to protect tribes
}

Rex Dalton, San Diego

Ethnobotanist Kelly Bannister feels strongly about protecting the rights of her research subjects in a native tribe in Western Canada - so strongly that she has previously put them ahead of her own rights to publish her work.

Now she is extending her philosophy into a programme called Community-University Connections. Already engaged in its first project, at the Clayoquot Biosphere Trust in British Columbia, the programme aims to help improve research collaborations between indigenous tribes and researchers.

The seeds of the idea were sown when Bannister was doing her doctoral thesis at the University of British Columbia in Vancouver. Guided by the elders of the Skeetchestn tribe, Bannister was studying plants with historic medicinal uses. In 1997, her academic adviser wanted to set up a collaboration with a drug company to study potential antimicrobial compounds identified by her research. But the tribe needed time to record and publish the knowledge of their elders, so Bannister denied her adviser access to the plant-assay data she had collected.

And in 2000 when she completed her doctorate, under a different supervisor, Bannister agreed to seal her thesis for five years to give the tribe time to prepare claims to any compounds that might be commercialized from the 70 plants she had analysed.

"I felt the data were going to be taken over and used for a purpose not in the best interest of the indigenous community," says Bannister. "I decided to take a stand; change requires people to stand up."

Now a postdoctoral fellow at the University of Victoria in British Columbia, Bannister is developing the Community-University Connections collaborative model for other researchers. She notes that the best interests of indigenous peoples often collide with the eagerness of most university researchers to publish information quickly. "Sometimes publications are not the best for the indigenous community," she says.

Ron Ignace, chief of the Skeetchestn tribe near Kamloops, British Columbia, claims that his people have been abused in the past by researchers who published their tribal history without permission. "Fortunately, this time we had someone with high moral fibre who worked with us," he says.

The tribe now plans to develop an ethnobotany research laboratory at the community's university campus. But with the lab still being planned and the data still under seal, work has yet to begin on Bannister's data.

Bannister and her colleagues agree that her approach can slow research projects, but they say that the results are worth the wait. Rod Dobell, a Victoria professor of public policy involved in the Community-University project, says that such negotiations "at the front end can prevent paralysing roadblocks later”.

Jo Render, a programme officer at First
Nations Development Institute, a Virginia group that fosters indigenous rights, says that Bannister's developing model shows great promise. "If people are willing to defend their thesis on the scientific results, why shouldn't they be willing to defend the process they use?" Render asks.

http://web.uvic.ca/ scishops
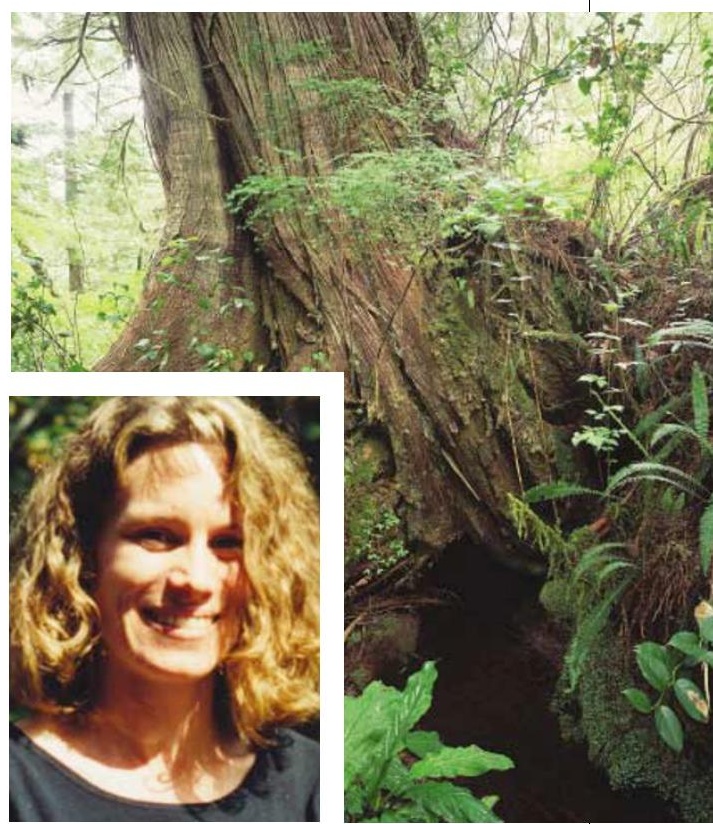

An ethical route: Kelly Bannister wants to see indigenous peoples benefit from research.

\section{Harvard mourns loss of popular evolutionary thinker}

\section{Erika Check, Washington}

Stephen Jay Gould, perhaps the best-known evolutionary theorist since Charles Darwin, died of lung cancer on 20 May. He was 60 years old and had been fighting against cancer since being diagnosed with mesothelioma two decades ago.

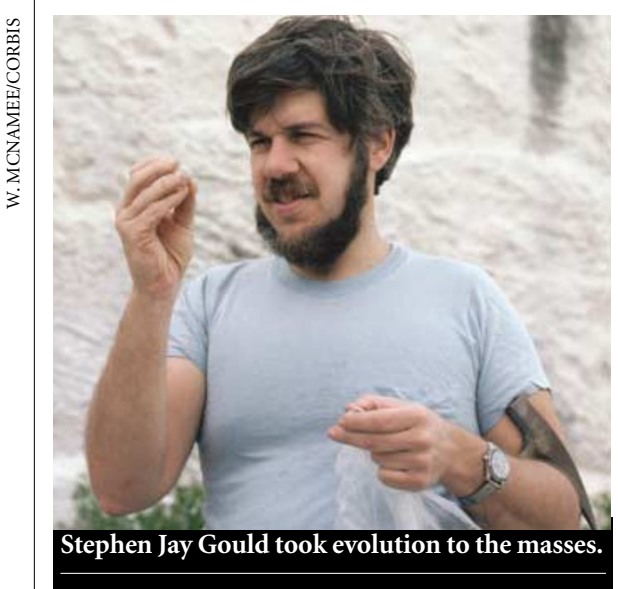

Gould, who spent almost his entire career at Harvard University, was famous for his outspoken views and wide-ranging intellect. He came to scientific attention in the early 1970 s by formulating the controversial theory of punctuated equilibria - which argues that evolution tends to occur in bursts, interspersed with long periods of relative stasis - with Niles Eldredge of the American Museum of Natural History in New York.

Gould's own research concentrated on the palaeontology and evolution of West Indian land snails, but it was through his elegant writing about evolution and other scientific mysteries that he really made his mark. He won acclaim for popular books such as The Panda's Thumb (1980), which won the American Book Award for Science, The Mismeasure of Man (1981), which won the National Book Critics Circle Award, and Wonderful Life (1989).

"Steve did not try to make it simple, he tried and succeeded in explaining the complications," says evolutionary geneticist Richard Lewontin, one of many Harvard colleagues to pay tribute. "He made readers appreciate how messy and variable life is."

Most recently, Gould published a massive intellectual tome, The Structure of Evolutionary Theory, a work he began more than 20 years ago (see Nature 416, 787; 2002). Gould also campaigned to ensure that evolution would be taught in US schools.

Born in New York City, Gould earned a bachelor's degree in zoology from Antioch College in 1963 and a $\mathrm{PhD}$ from Columbia University in 1967 . He then took a post at Harvard, eventually becoming the Alexander Agassiz Professor of Zoology in 1982.

Gould was also known for his nonscientific pursuits. He wrote enthusiastically about baseball and sang for many years with a Boston-area choir. He is survived by his second wife and two children from a previous marriage. - www.hno.harvard.edu/gazette/2002/05.16/ 99-gould.html 